\title{
Building Loyalty of Woman Cooperative Members through Perception and Trust
}

\author{
Endang Sungkawati \\ Wisnuwardhana University Malang \\ endang_sung@yahoo.co.id
}

\begin{abstract}
The loyalty of the members has an important role in the cooperative, maintaining it means maintaining the viability of the cooperative. This is the main reason for cooperatives to maintain the loyalty of its members. This research generally aims to analyze the influence of members' perceptions on the loyalty of members through the trust of women cooperatives in Blitar. The sample used is 251 members, sampling technique with purposive sampling. Data analysis method used is Structural Equation Modeling (SEM) technique. The results showed that the perception of members influenced the trust and loyalty of members. Likewise, member trust affects member loyalty. Once members have trust, then they will be willing to be active in every activity of Women's Cooperative. Trust of members in Women's Cooperative is a variable that can strengthen the influence of members perceptions, therefore, in order for members to get the benefits, cooperatives should be able to increase member loyalty. Based on this, women's cooperatives should be able to improve the perceptions and trust of members towards loyal members of the cooperative.
\end{abstract}

Keywords: perception, trust, loyalty, woman cooperative

\section{INTRODUCTION}

The loyalty of cooperative members can be formed by their belief in the existence of cooperatives. Hallowell [6] who argued that customer satisfaction is a prerequisite of customer loyalty. Loyal customers have a lower tendency to switch brands, are less price sensitive, buy more frequently or more, become the strong word of mouth, create business referrals. Opinion is also supported by research conducted by Akbar and Parvez [1] states that the factors that form customer loyalty are the quality of service, trust, and customer satisfaction. In addition to the trust of members of the cooperative, other factors become obstacles for the loyalty level of members of the cooperative. Based on the results of research Gray and Kraenzle [5] states that loyalty is influenced by many factors, including business type, business ownership, debt burden, member demographics, and member satisfaction. Members' satisfaction will establish trust in cooperative and cooperative management.
The level of member loyalty and the success of cooperatives cannot be separated from the concept of trust of its members [3], [5], [7], [9]. Members' trust is demonstrated by their involvement with the cooperative, by participating [5]. Members will believe in the cooperative if the cooperative can meet the needs of its members through mechanisms that meet the principles of cooperatives that have become an agreement [11]. Some research results say that the trust members have a positive correlation with the level of loyalty. That is, the higher the members trust, the greater the loyalty of members [2], [8], [12], [19].

Besides due to trust, members 'loyalty is also influenced by members' perceptions, members 'active roles and member discipline as well as members' knowledge of the fundamentals of cooperative management [14], [15], [16], [20]. Perceptions that have formed will affect the level of confidence of members, both against the cooperative itself and the board [4], [8], [10]. Obstacles to achieving the goals of cooperatives are usually caused by the level of knowledge and skills possessed by the community in this case members and management of cooperatives is still very limited. Based on the opinion above, negative perceptions and beliefs of members lead to low member loyalty. Moreover, in turn, when the loyalty of low members will cause the member's benefits also to be low. As members, they get less benefit from cooperatives [18].

Loyalty is a variable used to see the success of a cooperative. In theory as well as from the results of research, the important role of cooperatives can be realized through the active loyalty of members to activities organized by cooperatives, both loyalty as the owner of cooperatives and as the owner of cooperative services [5], [13]. However, in reality, the results of some empirical studies still show the low participation of members of the cooperative, but the cooperatives are still running. As previously described, the achievement of cooperative objectives is due to the lack of loyalty of members. Lack of member loyalty can be influenced by the perceptions and beliefs of members towards cooperatives. It is also possible to occur in women's cooperatives in East Java. Based on the results of the study, there are still cooperatives that failed or in the category of less good, i.e., by $20 \%$ [17]. The failure is indicated by the perception of the negative image of the cooperative and ultimately establishes the level of public confidence in the existence of woman cooperative. 
This study aims to determine the benefits and loyalty of cooperative members who are approached through organizational behavior theory. In other words, this study answers the question: do perceptions and trust affect directly or indirectly the loyalty of woman cooperative members in Blitar East Java? To know the effect, this research was developed by using quantitative approach. This research was conducted on women cooperatives located in BlitarEast Java Province.

Associated with the above, the hypothesis of this study is as follows. H1: member perceptions affect members' trust. H2: member perceptions affect member loyalty. H3: Members' trust affects member loyalty. H4: trust strengthens the influence of members' perceptions of member loyalty.

\section{METHOD}

This research used a quantitative approach and based on data analysis model. This study is categorized in analytic research to test the hypothesis. The number of research samples is 251 woman cooperative members. The data were collected by distributing questionnaires to the respondents. This study aims to examine and analyze the causal relationship between exogenous and endogenous variables, as well as check the validity and reliability of the research instrument as a whole. Quantitative analysis techniques are used to interpret and analyze data. In accordance with the multidimensional and tiered model developed in this research, we use Structural Equation Modeling (SEM) analysis technique using AMOS program.

\section{RESULT}

Structural Equation Model (SEM) analysis using AMOS was used to test the hypothesis proposed by the researcher. As a basis to test the hypothesis used Critical ratio $(\mathrm{Cr})$ from the output regression Weight. Where the hypothesis will be accepted if $\mathrm{p}$ value <of significance of $5 \%$. The results of the analysis can be seen in Figure 1. There are three types of influences to be presented in the structural model, namely Direct Effect, Indirect Effect, and Total Effect.

\section{Perceptions of Influential on Members Loyalty}

The result of coefficient analysis of SEM model line of direct influence of member perception variable to loyalty member obtained value 0,28 with $\mathrm{p}$-value equal to 0.000 , meaning that member's perception has a significant positive effect on member's loyalty. The higher the level of perception of the members results in the higher the loyalty of the members. Perceptions of members have a significant positive effect on member loyalty. This conclusion is based on the reality that members of Women's Cooperative are owners, controllers, and users whose existence as economic actors have perceptions that can support their loyalty in Women's Cooperative. The higher the perception of members of Women's Cooperative, the higher the loyalty in every activity of Women's Cooperative.

\section{Perceptions of Influential on Members Trust}

The result of coefficient analysis of SEM model line of direct influence of member perceptions variable on memberstrust obtained value 0,64 with $\mathrm{p}$-value equal to 0.006 , meaning that member's perception has a significant positive effect on Members Trust. Perceptions of members

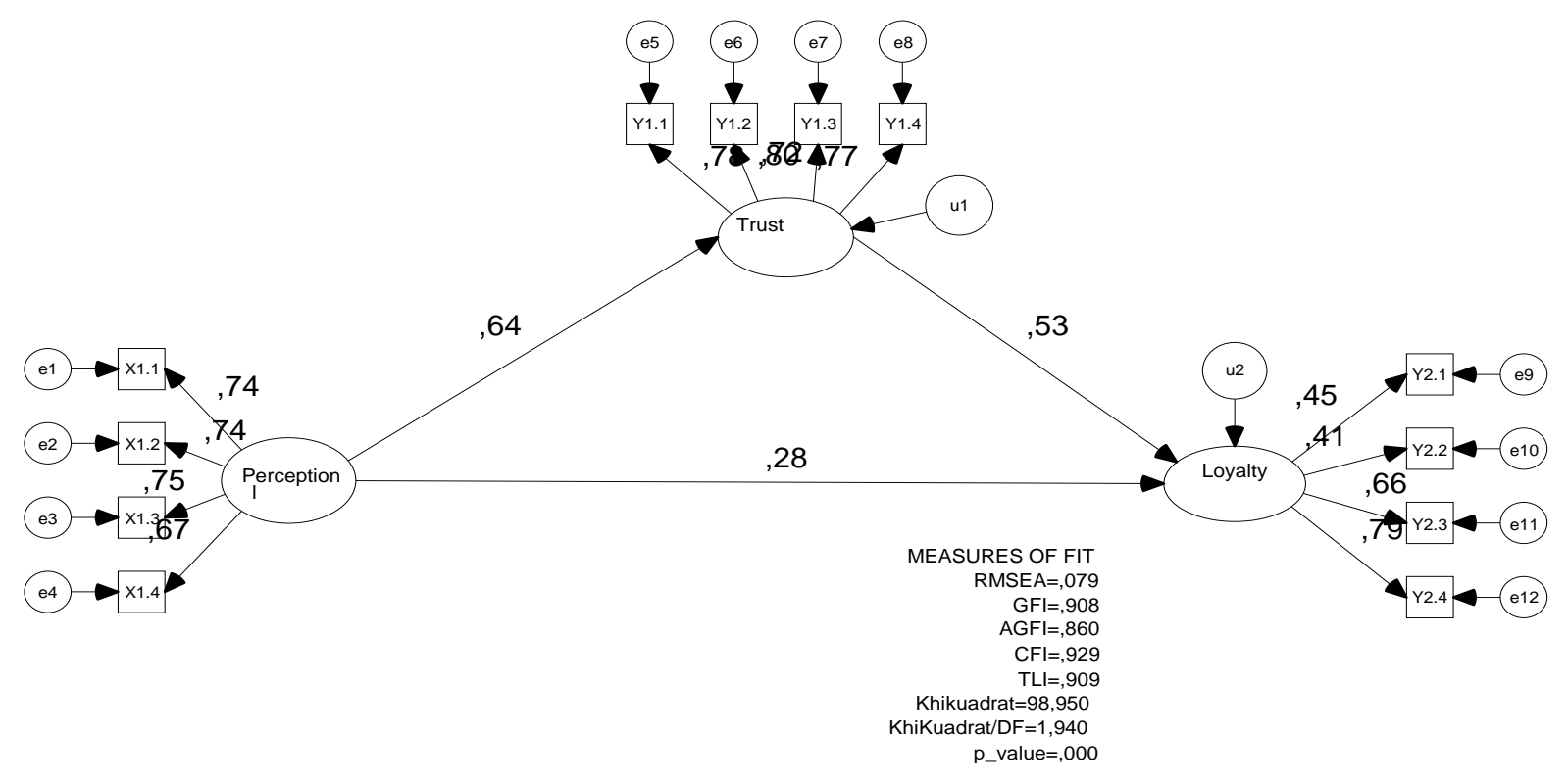

Figure 1. Result Structural Equation Model (SEM) 
have a significant positive effect on the Trust of Women Cooperative. Cooperative Women as an organization has advantages and disadvantages. This is what shapes the perception of members of the cooperative. However, the perception that has been formed has been able to form members' understanding on the Performance of Women's Cooperative.

\section{Member's Trust Influence on Member Loyalty}

The result of coefficient analysis of SEM model line of direct influence of trust member variable to member loyalty obtained value 0,53 with p-value equal to 0.000 , meaning trust member has a significant positive effect on member loyalty. The higher the trust of the members resulted in the higher the loyalty of members to the cooperative. With the trust of members, will motivate member loyalty. This conclusion is meant that, as one of the devices in charge of managing the Women's Cooperative and its business. It is expected that the board has the ability and can be trusted so as to increase the loyalty of the members as indicated by the increase of the loyalty of the members as owners, controllers, and users of Women's Cooperative. In addition, relationships among members with one another can also affect members' trust. The trust that has been formed on the members of the Women's Cooperative will be able to influence its loyalty.

\section{Members Trust Strengthening the Influence of Perception on Member Loyalty}

The indirect influence of member perception on members loyalty through member trust has a coefficient value equal to 0,197 , whereas great coefficient value influences direct perception member to Member Loyalty equal to 0,28 . The total effect is 0.477 . Based on these results, then the hypothesis that members trust moderate the influence of members perception on members Lloyalty is acceptable. These results indicate that the trust of members can strengthen the influence of perception members on Loyalty Members. Member Trust strengthens the influence of Members' Perception on the Loyalty of Women's Cooperative.

\section{CONCLUSION}

The result of the research shows that: (1) variable of perception and trust of the member have positive influence toward Loyalty of Women's Cooperative, (2) members trust variable strengthening influence of perception variable to the loyalty of Women Cooperative in Blitar. Perceptions that have formed in a person can influence them in taking a decision. Perceptions of members of Women's Cooperative in Blitar, formed by the stimulus of the cooperative and formed on him. The conformity between expectations and reality received by members of the Women's Cooperative has formed a positive perception that they are willing to be active and loyal to cooperative activities. In order to members to have confidence in the cooperative, it is necessary to have a concrete action from the board in the form of satisfactory and trustworthy service among members, since the trust of members can be used to build members' commitment and loyalty. Once members have trust, then they will be willing to be active in every activity of Women's Cooperative. Trust of members in Women's Cooperative is a variable that can strengthen the influence of members perceptions, therefore, in order for members to get the benefits of cooperatives, the Women's Cooperative should be able to increase member loyalty.

\section{REFERENCES}

[1] Akbar, M. Muzahid.,Parvez, Noorjahan. Impact of service quality, trust, and customer satisfaction on consumer loyalty, ABAC Journal, Vol. 29, No. 1, pp. 24-38, 2009.

[2] Bijman. J. Member or CustomerHarmer commitment to Supply cooperatives. Paper presented at the Internasional Conference The Economics and Management of Networks, Cyprus, $1-3$ December 2011.

[3] Debora. Pengaruh Pemberdayaan Kerja \& Psikologis terhadap .Kepercayaan Organisasi dan Kepuasan Kerja Dosen Tetap PTS. Jurnal Manajemen \& Kewirausahaan. 8(2): $61-71,2006$.

[4] Fulton. M. Cooperatives and MemberCommitment. The University of Saskatchewan, 2004.

[5] Gray \&Kraenzle. Member Participation in Agricultural Cooperatives: A Regression and Scale Analysis. United State Departement of Agriculture. RBS Research Report 165, 1998.

[6] Hallowell, Roger. The Relationships Of Customer Satisfaction, Customer Loyalty, And Profitability: An Empirical Study. International Journal Of Service Industry Management, Vol. 7, No. 4, pp. 27-42, 1996.

[7] Kennedy. MS, et al. Customer Trust for Sales and Manufacture.Journal of Bussines, 51: 73 -86, 2001.

[8] Kwon. Ik - Whan G. Factors Affecting the Level of Trust and Commitment in Supply Chain Relationship. The Journal of Supply Chain Management Springg. 2004: 4 - 14, 2004.

[9] Lawang R M.Z., Buku Materi Pokok Pengantar Sosiologi. Jakarta: Departemen Pendidikan dan Kebudayaan. Universitas Terbuka, 2005.

[10] Nilsson, J. Kihlénb, A. and Norellc L. Are Traditional Cooperatives an Endangered species? About Shrinking Satisfaction, Involvement and Trust IAMA: 12 (4): 101 - 122, 2009.

[11] Osterberg, P. Hakelius, K. Nilsson, J. Members Perception of Their Participation in Governance of Cooperatives: The Key to Trust and Commitment in Agricultural Cooperatives. Agribusiness. 25 (2): 181 $-197,2009$. 
[12] Powell, A. Galvin, J. Piccoli G. Antecedents to Team Member Commitment from near and far.Information Technology \& People. 19 (4): 299 - 322, 2006.

[13] Ropke, J, Kewirausahaan Koperasi; Dinamika Kewirausahaan dan Pengembangan Dalam Organisasi Swadaya, Sumedang: UPT Penerbitan IKOPIN, 2003.

[14] Rozi dan Etha. Ekonomi Koperasi. Jakarta: Penerbit Bintang, 2002.

[15] Sinaga.P. Relationship Between Group Cohesiveness, Achievement Motivation, Entrepreneurship Attitude, Member's Participation Attitude and Cooperative Performance in Bandung Regency Indonesia. Koperasi Dalam Sorotan Peneliti. Jakarta: PT Persada, 2005.

[16] Siswoyo. B. B. Faktor-faktor Eksternal Perilaku Organisasional Anggota Koperasi Dan Pengaruhnya Terhadap Partisipasi Anggota Dan Manfaat Anggota Koperasi. Jurnal Ekonomi Bisnis FE Universitas Negeri Malang, No 2, Vol 10, Agustus-2005
[17] Siswoyo.B.B.dkk. Penilaian Kinerja KoperasiWanita (Kopwan) Tahun 2009. LaporanPenelitian. Kerjasama Dinas Koperasidan UMKM Provinsi Jawa Timur dengan Fakultas Ekonomi Universitas Negeri Malang, 2011.

[18] Sungkawati. Endang. Gender-based cooperative educational program on woman cooperative in Blitar Regency, European Journal of Business and Management, ISSN (paper) 2222 - 1905; ISSN (online) 2222 - 2839, 2015.

[19] Xiao. Y. Zheng X, Pan W, DanXie XX, Trust, relationship commitment and cooperative performance: supply chain management. Chinese Management Studies. 4 (3): 111 - 124, 2010.

[20] Wijaya, dkk. Kewirausahaan Koperasi, Studi Kasus Koperasi Karyawan Universitas Surabaya. Surabaya: Brillian Internasional, 2010. 